\title{
Retirement timing in Italy: rising age and the advantages of a stable working career
}

\author{
Marco Trentini* (D) \\ Department of Education Studies “Giovanni Maria Bertin”, University of Bologna, Bologna, Italy \\ *Corresponding author. Email marco.trentini@unibo.it
}

(Accepted 20 January 2020; first published online 2 March 2020)

\begin{abstract}
This article looks at how retirement timing is changing in Italy. A first aim is descriptive and it is to identify recent trends in retirement age, following the pension reform. Then the focus is on factors which may favour or hinder the extension of the working career of older workers. They are studied by looking at the reasons for retirement, introducing the distinction between voluntary and involuntary retirement, and some predictors of retirement. Some of them relate to the work history of individuals, in particular the stability/instability of careers due to episodes of unemployment. The level of education and gender, two variables that may affect the employability of older workers, have also been considered. The study is based on a longitudinal analysis (Kaplan-Meier survival estimates of transition to retirement and binomial logit discrete-time model for the analysis of retirement predictors) of the Survey of Health, Ageing and Retirement in Europe (SHARE) Job Episodes Panel data. They refer to a sample of 1,999 individuals born between 1911 and 1959. Although the various pension reforms initiated in Italy in the 1990s have not yet been fully implemented, retirement age is rising, even in the case of involuntary retirement. Regarding work history, the advantages of a working career with a small number of unemployment episodes emerge from the study.
\end{abstract}

Keywords: retirement; timing; voluntary; involuntary; pension reform; work history; employability

\section{Introduction}

Many studies have been carried out on work-retirement transition (for a review, see e.g. Wang and Schultz, 2010; Sargent et al., 2012; Barbosa et al., 2016; Fisher et al., 2016). They show that it is a multi-disciplinary issue. This article will refer to the sociological perspective. The sociological approach stresses the importance of extending the analysis to variables considered less important by those economists that have analysed the retirement decision based on a work-leisure trade-off (see e.g. Blöndal and Scarpetta, 1999). ${ }^{1}$ The consequence, especially in studies using quantitative methodologies, is a modelling that shows that a number of predictors are important in the work-retirement transition.

\footnotetext{
(C) The Author(s), 2020. Published by Cambridge University Press. This is an Open Access article, distributed under the terms of the Creative Commons Attribution licence (http://creativecommons.org/licenses/by/4.0/), which permits unrestricted re-use, distribution, and reproduction in any medium, provided the original work is properly cited.
} 
The study of retirement predictors is connected with that of retirement timing, which can be defined as the age at which a worker retires (Fisher et al., 2016).

The age at which individuals retire has changed over time. According to the lifecourse approach (Elder and Giele, 2009; Mayer, 2009), retirement can be seen as a transition in the course of life conditioned by the characteristics of the subject (e.g. gender, level of education, health, marital status and family composition), individual history (e.g. work history), the interdependence of various spheres of life (family, work, etc.), and the constraints/opportunities posed by the institutional context such as the welfare system and the labour market (Wang and Shi, 2014; Fisher et al., 2016).

Studying retirement timing is a topic of great importance today as the context in which retirement takes place is changing (Fisher et al., 2016). While active ageing implies a redefinition of the social role of the elderly, it is above all the reform of pensions that pushes people in the direction of an extension of the working career. In many countries the statutory retirement age has been raised.

This article is about Italy. A first aim of the research is descriptive and is to analyse the current trends in retirement timing. Is the retirement age actually rising or does the pension reform need time to manifest its effects fully?

Another aspect to be explored is some factors/variables that may favour or hinder the extension of the working career of older workers (Blossfeld et al., 2006, 2011; Fisher et al., 2016; Leinonen et al., 2020). This study will focus on some that can be linked to employability. This is a topic less addressed by the literature on the predictors of retirement which, with regard to employment, considers aspects such as attitude to work, working conditions, job characteristics and job satisfaction (Blekesaune and Solem, 2005; Oakman and Wells, 2013; van Solinge and Henkens, 2014) or variables at organisational level (Feldman, 1994; Post et al., 2012): type of industry, firm size, human resource management practices, etc.

Raising the retirement age presupposes the employability of older workers. It is enough to remember that in the 1970s and 1980s, the early exit from the labour market was also due to the difficulties encountered by older workers due to unemployment and as a result of industrial restructuring (Kholi et al., 1991).

Employability can be defined as the capability of finding and retaining employment. In the case of older workers, for those who have a job, it means the ability to keep it over time. For those who are looking for work, because they want to return to the labour market or because they have to relocate, it means the ability to find a job.

Factors that may favour or hinder the extension of the working career will be studied, considering: (a) the reasons for retirement, introducing the distinction between voluntary and involuntary retirement (van Solinge and Henkens, 2007; Dorn and Sousa-Poza, 2010; Hofäcker et al., 2016; Riekhoff, 2016, 2018; Steiber and Kohli, 2017); and (b) the working history of individuals and in particular the ability to keep a job. The latter will be studied with reference to career stability/instability due to unemployment. Also whether a possible discontinuous employment history due to unemployment is a predictor of retirement will be analysed. In addition, two socio-demographic variables that may affect the employability of older workers will be considered: level of education and gender. 
Several reasons make it interesting to study Italy. First of all, Italy is defined as a case of 'early exit culture' (Contini and Foriero, 2002; Organisation for Economic Co-operation and Development (OECD), 2004; Reyneri, 2005). But now the retirement process in Italy occurs in a changed context. Moreover, in Italy the pension reform responds mainly to the aim of reducing social security expenditure, rather than redefining the role of the elderly also in work as envisaged by active ageing (Paci, 2005). Thus, forms of bridge employment that allow people to stay at work after retirement (Cahill et al., 2006; Fisher et al., 2016; Dingemans et al., 2017) have not been promoted. Instead, to safeguard workers close to retirement, flexible forms of retirement have been introduced that make it possible to exit the labour market before the statutory retirement age. Finally, older workers have a vulnerability factor in terms of employability, such as their low level of education, which is not compensated by widespread and substantial continuing education (ISFOL, 2006; OECD, 2019; Turek and Henkens, 2019).

The analysis will be based on longitudinal data, and more specifically on the Survey of Health, Ageing and Retirement in Europe (SHARE) data, mainly from the generated SHARE Job Episodes Panel (Orso et al., 2017a, 2017b). This is a further original element of the article since the lack of longitudinal data in Italy means that longitudinal studies are limited (and the few are based on data from the Longitudinal Study on Italian Families (ILFI), conducted between 1997 and 2005; see e.g. Schizzerotto, 2002; Beckstette et al., 2006; Barbieri and Scherer, 2011).

\section{Retirement timing: changing context and predictors}

The context in which retirement takes place has changed in the last 30 years, not only in Italy. Active ageing challenges the traditional representation of ageing as a lifestage dominated by physical and mental decline (Phillipson, 1998) and the identification of old people with retirement. Active ageing refers to the social role of older people. It has a broad meaning and implies participation in social, cultural and civic life, not only in the labour market. If we consider participation in the labour market, it is above all the reform of pensions that raises the retirement age and, therefore, pushes for an extension of the working career. Currently, the latter is one of the main labour policy objectives pursued by the European Union (Esping-Andersen et al., 2002). Economic and demographic reasons also contribute towards this aim, since the financial sustainability of current welfare state systems and above all of the pension systems has been questioned in an age of increasing life expectancy and improved health among the elderly. Labour policy towards older workers is consequently changing: especially during the 1980s, in order to tackle unemployment, attempts were made, albeit in different ways in each European country, to reduce labour supply by encouraging labour market exits, including by means of early retirement (Kholi et al., 1991; Auer and Fortuny, 2000).

Since the trend towards a higher retirement age is quite recent, it is important to study how retirement timing is actually changing (Fisher et al., 2016). According to the OECD (2017), in many countries, including Italy, there is still a gap between the effective average retirement age and the statutory retirement age.

It can be assumed that this is due to various factors. First of all, in many countries flexible forms of retirement have been introduced that allow pensions to be 
drawn before (or even after) the official pension age (OECD, 2017). For example, in Italy in 2019, there are 12 different ways to exit the labour market before reaching the statutory retirement age. Moreover, welfare reform policies must be implemented. Welfare has shown a capacity for resilience to change (Pierson, 2001), especially in the case of unpopular reforms that have provoked strong opposition, such as in the case of pensions. Thus, in many countries, including Italy, pension reform will only fully manifest its consequences on the younger generations.

In addition to these reasons linked to the pension reform process, the focus must also be shifted to factors/variables at an individual level that may favour or hinder the extension of the working career of older workers. The reasons for retirement and the stability/instability of work history due to unemployment will be analysed, as mentioned above.

A first aim of the study is, therefore, descriptive. It consists of identifying the current trends in retirement timing in Italy, considering some aspects related to the retirement process: pension reform and the reasons for retirement.

The pension system is the main focus of Italian research into the retirement decision. The 'early exit culture' is usually considered an outcome of institutional arrangements: the Italian pension system provided strong incentives for an early exit from the labour market not only during the restructuring years (mid-1970s to 1980s), thanks to a high pension replacement rate, whereby the pension is very close to the previous wage/salary, and to the availability of seniority pensions (Contini and Foriero, 2002; Marano and Sestito, 2004; OECD, 2004) which, until 2011, made it possible to retire before reaching pensionable age, with 40 years of contributions regardless of age.

The pension reforms (of 1992, 1995, 2001, 2004, 2007 and 2011) sought to increase the activity rate by raising the retirement age (to 67 years for both men and women starting from 2019, but since 2011 there is a link between retirement age and life expectancy) and by reforming the entitlement to seniority pensions. Moreover, in order to improve financial sustainability, there has been a switch from a pay-as-you-go system to a contributory system for workers with less seniority.

Another variable that may affect retirement timing is the reason for retirement. This is a topic that has been little studied especially in Italy, but which is of considerable importance. The distinction between voluntary and involuntary retirement (van Solinge and Henkens, 2007; Dorn and Sousa-Poza, 2010; Hofäcker et al., 2016; Riekhoff, 2016, 2018; Steiber and Kohli, 2017) shows that the decision to exit the labour market is not always taken by the worker of his or her own free will. Retirement can be defined as voluntary if it occurs because the worker has complied with the requisites established by the social security system, or of his or her own free will (e.g. to retire at the same time as his or her partner, out of a preference for free time, etc.); it can be defined as involuntary if it is attributable to unpredictable events beyond the worker's control, such as health conditions (the worker's own, or those of relatives or friends), care responsibilities or expulsion from the labour market.

The distinction between voluntary and involuntary retirement recalls the distinction between the pull factors (the incentives - benefits and eligibility rules - provided by the social policies) and push factors (e.g. health conditions, the high 
unemployment rate and redundancies due to corporate restructuring) (Kholi et al., 1991). Looking at the reasons for retirement also makes it possible to identify possible vulnerabilities of older workers that may affect their labour market participation.

The description of the trends in retirement age in Italy will be followed by a study of some predictors of retirement, with a focus on work history and especially on work stability/instability due to episodes of unemployment. Not only is work history a neglected topic in recent longitudinal studies on determinants of retirement timing, ${ }^{2}$ but analysing the stability/instability of the career due to unemployment will address the issue of the ability to keep a job that is a requirement for the extension of the working career.

In a comparative study, Blossfeld et al. (2006) maintain that the changes in the structure of qualifications brought about by globalisation are leading to the identification in various countries of two ideal types of strategy for the adaptation of the older workforce: employment maintenance and employment exit. The former is based on greater mobility at work even in late career and on lifelong learning. The latter contemplates an early exit from the labour market. The authors assert that Italy falls into the latter category.

The advantages of a stable career are clear. It might favour retirement because the entitlement conditions of the pension schemes are more likely to be met (Schils, 2008).

The relationship between unemployment and retirement is more controversial. On the one hand, an unstable career due to unemployment can lead to an early exit from the labour market. On the other hand, a lower level of continuity in work can have a negative impact on contributions paid and therefore on pensions (as well as accumulated wealth) and lead to a later exit from the labour market.

The effect of unemployment can vary depending on the career stage: it is at the late career stage that it can lead to retirement because of the lack of opportunities in the labour market (Chan and Stevens, 2004; Ponomarenko, 2016). At the start of an individual's career, on the other hand, and especially upon entry to the labour market, unemployment can lead to the acceptance of poorly paid or less-secure employment (Ponomarenko, 2016). Moreover, the effects of unemployment throughout an individual's career are the result of a number of disadvantages that build up (Ponomarenko, 2016), in the sense that particularly fragmented careers can have a negative impact on aspects such as career opportunities and income. In addition, loss of employment can have negative effects on an individual's wellbeing.

Overall, therefore, unemployment can increase the vulnerability of an older worker in terms of employability, health conditions, income insecurity in later life, etc.

In the study of retirement predictors, the focus will also be on the level of education and gender. As mentioned above, they are two variables which can affect the employability of older workers.

Human capital is regarded as being of crucial importance for the extension of the working career (Esping-Andersen et al., 2002; Turek and Henkens, 2019). Older workers may be at risk of skills and professional obsolescence. When considering education and training, older workers in Italy have vulnerabilities. Not only 
older Italian workers possess lower qualifications, but they are also at high risk of exclusion from continuing training. Italian companies are less active than those of other countries in this field. Therefore, the participation of workers in continuing training is rather low (ISFOL, 2006; OECD, 2019; Turek and Henkens, 2019). Moreover, access to it is highly selective. The opportunities to receive continuing training are influenced by individual variables: sex, age, educational qualification, job. Those most penalised are women, older workers, workers with low educational qualifications and those in low-skill jobs.

Gender, as is well known, is a variable of differentiation primarily in labour market participation. In Italy, the low level of activity among the elderly was due not only to early retirement but also to low levels of employment among women (Contini and Foriero, 2002; OECD, 2004; Reyneri, 2005). Mention should be made of the familist welfare regime (Esping-Andersen, 1990) and of the limited spread of part-time work (Reyneri, 2005).

The literature shows that the effects of gender on retirement timing are not unique (see e.g. Ginn and Arber, 1996; Loretto and Vickerstaff, 2015; Fisher et al., 2016). According to some research, women tend to retire earlier for reasons related to their care activities and the difficulty of reconciling them with work, or to a weakness in the labour market due to low levels of education and a fragmented career. As reported in other studies, instead, women tend to stay longer in the labour market for various reasons: to compensate for the retirement disadvantages of a fragmented working career or to maintain their acquired status in the labour market.

\section{Data and methods}

As already mentioned, this study is based on the SHARE data, above all from the generated SHARE Job Episodes Panel (Brugiavini et al., 2013; Antonova et al., 2014; Orso et al., 2017a, 2017b). The data-set rearranges information taken from release 6.1.0 of Wave 1 (2004) and Wave 2 (2006) and 6.0.0 of Wave 3 (SHARELIFE 2008-2009).

Wave 3 (SHARELIFE) collected retrospective information of the respondents, concerning events occurring throughout their entire life before the baseline year of the survey. Since SHARE respondents are individuals aged 50 years or older, the information collected concerns a wide timespan with all the consequences that it can have on data quality. Retrospective data collection may suffer from recall bias or error. However, the quality of the SHARELIFE data has been evaluated very positively (Schröder, 2011).

The SHARE Job Episodes Panel is an event data-set for each individual in the sample, containing information drawn from the work history section of the questionnaire.

The data analysed refer to a sample of 1,999 individuals, born between 1911 and 1959, who have worked (regardless of how long). ${ }^{3}$ In the longitudinal analysis for each respondent, account was taken of the period of time ranging from the age of 15 to 60 years. It may be assumed to comprise the work history of most of those interviewed, considering that the average age at which they concluded their studies was 14.6 years (standard deviation $(\mathrm{SD})=5.1$ ) and the average retirement age was 56.8 years $(\mathrm{SD}=6.1)$. 
Since the descriptive information present in the longitudinal file is rather limited, it was supplemented by creating a (non-longitudinal) data file based on the SHARE data from the first three waves, and specifically release 6.1.0 for Waves 1 and 2, and release 6.0.0 for Wave 3 (SHARELIFE). A key variable included is whether retirement is voluntary or involuntary (referring to the question on the reason for retirement). Clearly, this file includes data relating only to subjects also present in the longitudinal file.

As stated earlier, the focus of the research is on retirement timing. There is no clear, unambiguous definition of retirement timing (Fisher et al., 2016). Some studies refer to the age at which a worker exits the labour market and therefore ceases to be part of the workforce; others refer to the source of income (specifically being paid a pension) (Riekhoff, 2016, 2018). This article will refer to the former, considering an individual as retired according to the self-reported current job situation.

As regards the socio-demographic variables, since SHARE interviewees, as said, must be aged at least 50 years at the baseline, they were divided into three birth cohorts of similar size (number of years): 1911-1927, 1928-1944 and 1945-1959. Education was classified into four levels according to the International Standard Classification of Education (ISCED 1997).

In the case of workers who have already retired, the distinction between voluntary and involuntary retirement is based on the SHARE question on the reason for retirement. Taking Hofäcker et al. (2016) as a reference, which for Germany uses the SHARE data, the reasons for voluntary retirement are: became eligible for public pension; became eligible for private occupational pension; became eligible for a private pension; was offered an early retirement option/window (with special incentives or bonus); to retire at same time as spouse or partner; to spend more time with family; and to enjoy life. The reasons for involuntary retirement are: made redundant (e.g. pre-retirement); own ill health; and ill health of relative or friend.

In the study of the work history, work stability/instability was investigated looking at episodes of unemployment. In the SHARE Job Episodes Panel an unemployed dummy was generated based on the respondent's report of their status between each job episode or spell (Brugiavini et al., 2013; Antonova et al., 2014; Orso et al., 2017a, 2017b). In the same way, a retired dummy variable was generated.

The industry was grouped into primary, secondary and tertiary, according to the International Standard Industrial Classification of all Economic Activities (ISIC). The job titles are employee and self-employed.

The longitudinal analysis was conducted with the usual methodologies: KaplanMeier survival estimates for the descriptive analysis of the transition to retirement and binomial logit discrete-time model. The discrete-time model was deemed more appropriate, since the data contain information on working episodes, unemployment episodes, etc., collected annually, that is with a yearly measurement of events (Mills, 2011; Singer and Willett, 2003).

The data analysis was carried out using R Commander (version 2.4-4).

Table 1 shows the socio-demographic profile of the respondents and the work situation at the time of the last interview.

The sample is composed of a majority of men (54.13\%). The largest cohort comprises those born between 1928 and 1944 (51.28\%), followed by the cohort 
Table 1. The socio-demographic profile of the interviewees

Gender:

Female

Male

Birth cohorts:

1911-1927

1928-1944

1945-1959

Education level:

Primary

Lower secondary

Upper secondary

Tertiary

Current job situation:

Retired

Employed or self-employed

Unemployed

Permanently sick or disabled

Home-maker

Other

1945-1959 (42.47\%). Educational qualifications are for the most part rather low: 48.62 per cent of those interviewed have completed primary education only, and just 7.57 per cent have a tertiary level of education.

As regards their work situation at the time of the interview, there is a clear prevalence of pensioners (60.82\%). Those in employment account for 23.10 per cent and home-makers for 12.78 per cent. The percentages accounted for by the unemployed $(0.55 \%)$ and permanently sick or disabled $(1.29 \%)$ are very small.

\section{The consequences of pension reforms: the retirement age is rising}

The Kaplan-Meier survival estimates of the transition to retirement (45-60 age bracket) and the average retirement age were taken into account to describe the current trends in retirement timing. As is evident in Figure 1, the Kaplan-Meier survival estimates show that the probability of surviving retirement is lower after the age of 54 years; after this age, the curve is markedly downward. ${ }^{4}$ 


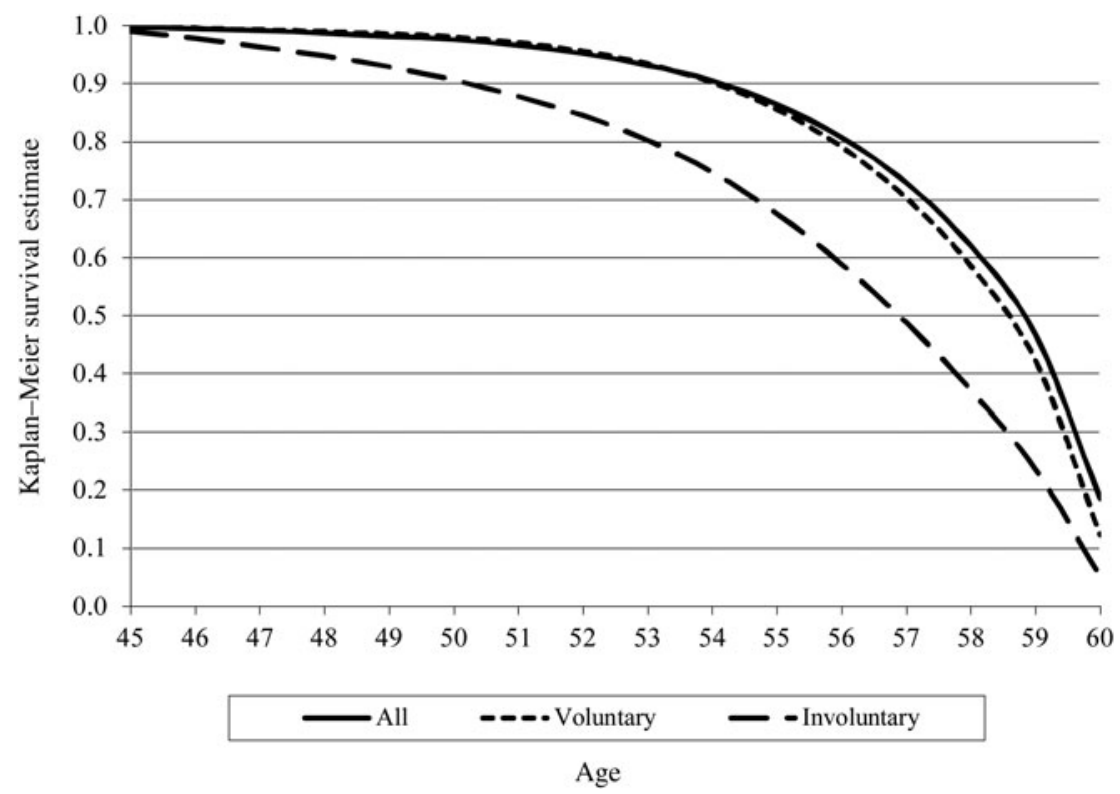

Figure 1. Transition to retirement, age 45-60, all and by type of retirement (voluntary and involuntary).

As one might expect, retirement timing is affected by the reason for retirement, particularly if it is voluntary or involuntary. In the case of Italy, a clear majority of retirements are voluntary $(87.00 \%$; Table 2$)$.

More specifically, almost 80 per cent of retirements are due to having reached the requisites for a pension (public mainly, and to a much smaller extent, private). The percentage of respondents who decide to retire at the same time as their spouse or partner is negligible $(0.09 \%)$. Involuntary retirement is due to health reasons (own ill health, 8.73\%, and to a very small extent, ill health of a relative or friend, $0.87 \%$ ), and for 3.40 per cent of interviewees it is due to being made redundant.

As is evident in Figure 1, the curve of the Kaplan-Meier survival estimates in the case of involuntary retirement is lower than the curve in the case of voluntary retirement, which means that the survival probability at the retirement event is lower.

The trends in retirement timing are also analysed looking at how the average age at retirement varies with some variables related to retirement. With regard to the average it should be noted that, although the quality of the SHARE data was assessed positively, the recall error in the year of retirement (Korbmacher, 2016) means that a measure of caution must be exercised with regard to the value of the average retirement age. Therefore, rather than on each average age value, this study will focus on what seem to be the trends with regard to retirement timing.

In 2009 , the average retirement age was 56.8 years $(S D=6.1)$. As one would expect, the reason for retirement, and more precisely if it is involuntary, lowers 
Table 2. Reasons for retirement

\begin{tabular}{|c|c|}
\hline \multicolumn{2}{|l|}{ Reason: } \\
\hline Became eligible for public pension & 66.05 \\
\hline Became eligible for private occupational pension & 12.04 \\
\hline Became eligible for a private pension & 0.70 \\
\hline Made redundant (e.g. pre-retirement) & 3.40 \\
\hline Was offered an early retirement option/window (with special incentives or bonus) & 2.97 \\
\hline Own ill health & 8.73 \\
\hline Ill health of relative or friend & 0.87 \\
\hline To retire at same time as spouse or partner & 0.09 \\
\hline To spend more time with family & 4.10 \\
\hline To enjoy life & 1.05 \\
\hline \multicolumn{2}{|l|}{ Type of retirement: } \\
\hline Voluntary & 87.00 \\
\hline Involuntary & 13.00 \\
\hline Total & 100.00 \\
\hline Missing & 68 \\
\hline $\mathrm{N}$ & 1,214 \\
\hline
\end{tabular}

the average retirement age (involuntary: mean 53.8 years, $\mathrm{SD}=6.5$; voluntary: mean 57.1 years, $\mathrm{SD}=5.9$ ). The pension reforms have led to a rise in pensionable age. Although the various reforms have not yet been fully implemented, they appear to be showing their effects in terms of delayed exit from the labour market. This is evident if we consider average retirement age before 1995 and after 1996, the year which can be considered a watershed in the process of pension reform in Italy (until 1995: mean 55.1 years, $S D=6.8$; since 1996: mean 58.5 years, $\mathrm{SD}=4.7$ ).

The descriptive data analysis shows two characteristics of the retirement timing in Italy: at least until 1995, there was a trend towards shortening of the work career. Since then, the consequences of the pension reforms have led to a rise in the retirement age. The reasons for retirement also have an effect on retirement timing: when they are involuntary, the age is lowered. Therefore, the reason for retirement and the pension reform are pushing in different directions as far as retirement timing is concerned.

However, if the average age by type of retirement is analysed by period (before and after the reform), the effects of pension reforms seem to prevail (Table 3). Indeed, for those who retire from 1996 onwards, the average retirement age rises whether they retire involuntarily or involuntarily. The average age difference between the two types of retirement tends to narrow. 
Table 3. Average retirement age by type and year of retirement

\begin{tabular}{|c|c|c|c|c|c|}
\hline \multirow[b]{3}{*}{ Type of retirement } & \multicolumn{4}{|c|}{ Year of retirement } & \multirow[b]{3}{*}{$\mathrm{N}$} \\
\hline & \multicolumn{2}{|c|}{ Until 1995} & \multicolumn{2}{|c|}{ Since 1996} & \\
\hline & Mean & SD & Mean & SD & \\
\hline Voluntary & 55.6 & 6.6 & 58.5 & 4.7 & 750 \\
\hline Involuntary & 51.8 & 6.5 & 57.4 & 4.7 & 91 \\
\hline $\mathrm{N}$ & 415 & & 426 & & \\
\hline Missing & & & & & 373 \\
\hline Total & & & & & 1,214 \\
\hline
\end{tabular}

Note: SD: standard deviation.

\section{The advantages of a working career with a small number of unemployment episodes}

Following the descriptive analysis, it will now be considered whether and to what extent some predictors influence retirement. As mentioned above, in addition to the usual socio-demographic variables, reference will be made to some variables related to work history: industry, job title and, in particular, to the stability/instability of the career due to episodes of unemployment.

To determine the predictors of retirement, a binomial logistic regression model has been used. A discrete-time model was opted for, since the information was collected on a yearly basis (Singer and Willett, 2003; Mills, 2011) and we know only the year when the retirement event occurs.

Following Singer and Willett (2003), the various models were constructed, first regressing the event indicator (retirement) on time (age and age squared in order to include a quadratic level) (Model 1). Then, the predictors are included: sociodemographic variables (gender, level of education, birth cohort) (Model 2), followed by variables linked to work history, which also include time-varying predictors: the industry (primary, secondary and tertiary), the job title (employee or self-employed) both treated as dummies and being unemployed (Model 3).

Based on Akaike information criterion, the model with the best explanatory capacity is Model 3 (Table 4).

Considering the odds ratio $(\exp b)$, it is clear that - as was predictable - the likelihood of being retired increases with age. The significance of the age squared variable and the sign of the coefficient shows that the relationship between age and retirement is quadratic and, more precisely, the curve tends to open up.

Looking at the socio-demographic variable, gender is not a significant variable, at least in Model 3. Consistent with the literature is the fact that those with a tertiary level of education are less likely to be retired than those with a primary level of education. The odds of retirement are 0.575 times lower for those with tertiary education compared to those with primary education (that is the odds ratio changes by $-42.5 \%$ switching from primary education, the reference category, to tertiary education). 
Table 4. Transition to retirement: binomial logit discrete-time models

\begin{tabular}{|c|c|c|c|c|c|c|}
\hline & \multicolumn{2}{|c|}{1} & \multicolumn{2}{|c|}{2} & \multicolumn{2}{|c|}{3} \\
\hline & & $\exp b$ & & $\exp b$ & & $\exp b$ \\
\hline Intercept & $-8.065^{\star \star \star}$ & 0.000 & -8.193 & 0.000 & $-9.223^{* * *}$ & 0.000 \\
\hline Age & -0.016 & 0.983 & 0.016 & 0.984 & 0.007 & 1.007 \\
\hline $\mathrm{Age}^{2}$ & $0.003^{\star \star \star}$ & 1.003 & $0.003^{\star \star \star}$ & 1.003 & $0.002^{\star \star \star}$ & 1.002 \\
\hline \multicolumn{7}{|l|}{ Gender (Ref. Female): } \\
\hline Male & & & $0.166^{\star \star \star}$ & 1.181 & -0.094 & 0.910 \\
\hline \multicolumn{7}{|l|}{$\begin{array}{l}\text { Education level } \\
\text { (Ref. Primary): }\end{array}$} \\
\hline Lower secondary & & & $0.175^{\star \star \star}$ & 1.192 & -0.125 & 0.881 \\
\hline Upper secondary & & & $0.309^{\star \star \star}$ & 1.363 & -0.027 & 0,974 \\
\hline Tertiary & & & $-0.257^{\star \star \star}$ & -0.773 & $-0.554^{\star \star \star}$ & 0.575 \\
\hline \multicolumn{7}{|l|}{$\begin{array}{l}\text { Birth cohort } \\
\text { (Ref. 1928-1944): }\end{array}$} \\
\hline $1911-1927$ & & & $-0.194^{\star \star}$ & 0.824 & $-0.275^{\star}$ & 0.760 \\
\hline $1945-1959$ & & & $-0.160^{\star \star \star}$ & 0.853 & $-0.259^{\star \star \star}$ & 0.772 \\
\hline \multicolumn{7}{|l|}{ Industry: } \\
\hline Secondary (dummy) & & & & & 0.038 & 1.038 \\
\hline Tertiary (dummy) & & & & & $-0.689^{\star \star \star}$ & 0.502 \\
\hline \multicolumn{7}{|l|}{ Job title: } \\
\hline Employee (dummy) & & & & & $0.173^{\star}$ & 1.189 \\
\hline Unemployed & & & & & 0.893 & 2.443 \\
\hline AIC & 26,930 & & 26,756 & & $7,990.5$ & \\
\hline
\end{tabular}

Notes: Ref.: reference category. AIC: Akaike information criterion.

Significance levels : ${ }^{\star} p<0.05,{ }^{\star \star} p<0.01,{ }^{\star \star \star} p<0.001$.

As a reference, the birth cohort chosen was 1928-1944 which is the most populated. For both the 1911-1927 and 1945-1959 cohorts, the value of the odds ratio is less than 1 . Therefore, the two cohorts have a negative effect on the odds of being retired ( 0.760 and 0.772 times lower, respectively) compared with the reference cohort (1928-1944). The odds ratio has a percentage variation of -24.0 and -22.8 per cent, respectively. The fact that, for the other variables being equal, the odds of being retired of the 1911-1927 cohort is lower, can be interpreted as the consequence of a longer working career of those born in that cohort compared to the cohort taken as reference. It should also be borne in mind that it is the 1928-1944 cohort that benefited most from the early retirements that were widespread in Italy especially during the 1980s. In the case of the 1945-1959 cohort, the negative effect on the odds of being retired compared to the 1928-1944 cohort may be due to the fact that it is the youngest cohort. 
Moreover, the rise in the level of educational qualifications led to later entry into the labour market. The consequences of pension reforms also have a major impact on this birth cohort. Differences by birth cohort show that, in Italy, early retirement is a phenomenon that mainly concerns the intermediate cohort between the three identified (1928-1944), while the other two cohorts (19111927 and 1945-1959), although for different reasons, tend to have longer working careers and to retire later.

As regards the variables related to work history, the industry variable is significant, that is being employed in the tertiary sector compared to the primary and secondary sector. The odds of retirement is 0.502 times lower for those working in the tertiary sector (the odds ratio changes by $-42.5 \%$ switching from tertiary to the primary and secondary sectors). Instead, being an employee raises the likelihood of retirement compared to being self-employed (the odds of retirement is 1.189 and the odds ratio changes by 18.9 per cent moving from employee to a self-employed status). The results are consistent with the findings of other research (see e.g. Fisher et al., 2016): those employed in the service sector and the self-employed have a propensity to retire later than those employed in the primary and secondary sectors and employees.

Contrary to expectations, having been unemployed is not significant. To interpret this fact, it may be useful to estimate the Kaplan-Meier survival function of the transition to unemployment.

According to the SHARE Job Episodes Panel, the risk of unemployment of the interviewees is decidedly low throughout all their work history. The Kaplan-Meier survival estimates range from 0.998 at 15 years to 0.913 at 60 years. The low level of education does not seem to be a factor of vulnerability. The Kaplan-Meier survival estimates by level of education show that differences are very small and are between those with tertiary education and others. The risk of unemployment is a little higher for those without a tertiary level of education.

The Kaplan-Meier survival function of the transition to unemployment allows it to be stated that the non-significance of the variable being unemployed in Model 3 may be due to the fact that respondents have a rather stable employment history, with a low risk of being unemployed.

\section{Discussion and conclusions}

Retirement, not only in Italy, is taking place in a changing context. This study is intended to contribute to an open debate on both substantive and methodological aspects.

As far as the former are concerned, the literature review has shown the need for studies on retirement timing. Among the open questions is whether there is actually a trend towards a rise in the retirement age and which are the main predictors that explain retirement timing (see e.g. Barbosa et al., 2016; Fisher et al., 2016; Hofäcker et al., 2016).

From a methodological point of view, the need for longitudinal studies has been identified (Fisher et al., 2016). While most of the research is cross-sectional, the temporal dimension of retirement must also be taken into account from a methodological point of view. This means looking at the impact on retirement timing 
of events prior to retirement, linked to the development over time of the biographies or trajectories of individuals.

A first aim of the research was to identify the trends in retirement timing in Italy following the pension reform.

According to the analysis of the SHARE data collected in 2004, 2006 and 20082009 , in Italy there is a trend towards an increase in retirement age. The descriptive analysis of the data carried out both with the Kaplan-Meier survival estimates of the transition to retirement and considering the average retirement age has confirmed that variables related to retirement affect retirement age. They are the reason for retirement, which can be summarised in the distinction between voluntary and involuntary retirement. The second, as one might expect, leads to a lowering of the retirement age. Instead, it is the pension reform process that started in the 1990s which is driving up the retirement age. The increase in age also affects involuntary retirement and, therefore, the age difference with voluntary retirement tends to narrow.

Raising the retirement age does not necessarily mean Italy is abandoning the 'early exit culture'. Many studies on retirement timing focus on the distinction between early, on time or later retirement (Kholi et al., 1991; Feldman, 1994; Blekesaune and Solem, 2005; Schils, 2008, Dorn and Sousa-Poza, 2010; Hofäcker et al., 2016; Axelrad, 2018; to name a few). The most common definition considers early retirement as occurring before the statutory retirement age (e.g. Kholi et al., 1991). Although the subject has not been addressed in this research, ${ }^{5}$ it can be hypothesised that an 'early exit culture' is changing compared to the years before the pension reform but has not been abandoned in Italy. The data refer to a period in which pension reform has not yet fully manifested its effects. Until 2011, it was possible to retire before reaching statutory pensionable age, with 40 years of contributions regardless of age. Various forms of flexible retirement still exist allowing people to exit the labour market before the statutory retirement age.

A second aim of the research was to analyse whether some factors that can be linked to employability adversely affect the extension of the working careers of older workers.

Reference was made first to the reasons for retirement. The descriptive analysis showed that 13 per cent of retirements can be defined as involuntary. They are mostly due to health reasons ( $74 \%$ of involuntary retirements). It is confirmed that health conditions are a predictor of retirement (Disney et al., 1997; Humphrey et al., 2003; Börsch-Supan et al., 2009; Avendano and Mackenbach, 2010). About a quarter of involuntary retirements appear to be directly attributable to occupational difficulties that lead to an exit from the labour market (being made redundant).

The analysis of retirement predictors carried out with a discrete-time model (binomial logistic regression model) analysed career stability/instability due to unemployment episodes. The sample of respondents analysed shows a working career characterised by high stability, in the sense of a very limited number of episodes of unemployment, throughout their lives (the timespan considered is from the age of 15 to 60 years). This is also true from the age of 45 years, which is often taken as a baseline for studying late careers. This is difference with respect to those who, talking about the impact of globalisation on late careers, defined Italy as an example 
of an employment exit strategy, due to the vulnerability of older workers in the labour market (Beckstette et al., 2006; Blossfeld et al., 2006).

Two socio-demographic variables that may affect the extension of participation in the labour market are the level of education and gender.

The low level of education of most of those interviewed (almost $70 \%$ of those interviewed have only a primary or lower-secondary level of education) does not represent a disadvantage in terms of the stability of their work history (in terms of episodes of unemployment). This can be explained by several factors. For instance, the characteristics of the Italian industrial system, with a predominance of small, not always very innovative businesses and with limited internationalisation. Moreover, in Italy, training often occurs informally on the job and therefore valorises work experience. Contrary to what could be expected, the low level of education of the workforce does not therefore seem to have had an impact on the ability to keep a job for the majority of older workers. Instead, a low level of education also means early entrance into the labour market and thus the chance to accumulate seniority rights and to leave the labour market early (until when the seniority rules were less stringent).

In the research presented here, gender is not a significant variable, at least in Model 3 (see Table 4). In some respects, this may seem surprising given that in Italy, as said, the patterns of labour market participation differ between the genders. It is, however, a consistent result with those of other research that have shown that one of the anomalies of Italy compared to other countries is that the average retirement age of women in recent years is not very different than for men and tends to be higher (De Luigi et al., 2016). This appears to be due to greater fragmentation of women's working careers and to a sort of self-selection of women who reach retirement at statutory age. Given the low levels of female employment, those women who remain in the labour market longer are a small, particular category, with a strong attachment to their work.

In conclusion, overall, the research shows that in Italy there is a trend towards raising the retirement age. Moreover, most of the workers interviewed benefit from the advantages of a career with a very low number of unemployment episodes, despite factors of potential disadvantage such as their low level of education.

Retirement at an age lower than the statutory one for the majority of workers appears to be influenced by pull rather than push factors, i.e. the characteristics and benefits of the pension system rather than a vulnerability related to their employability.

Clearly, given that the SHARE data analysed here were collected in 2008/2009 as a last year, it remains to be seen whether the importance of the pull and push factors has changed in recent years, taking account of the fact that seniority pensions, the main way of flexible retirement, were abolished in 2012, and of the impact of the 2007/2008 economic crisis.

Supplementary material. The supplementary material for this article can be found at https://doi.org/10. 1017/S0144686X20000148.

Data. This paper uses data from SHARE Waves 1, 2 and 3 (SHARELIFE), see Börsch-Supan et al. (2013) for methodological details, and data from the generated Job Episodes Panel (doi:10.6103/SHARE.jep.600), see Brugiavini et al. (2013) and Antonova et al. (2014) for methodological details. The Job Episodes Panel 
release 6.0.0 is based on SHARE Waves 1, 2 and 3 (SHARELIFE) (DOIs: 10.6103/SHARE.w1.611, 10.6103/ SHARE.w2.611, 10.6103/SHARE.w3.611). The SHARE data collection has been primarily funded by the European Commission through FP5 (QLK6-CT-2001-00360), FP6 (SHARE-I3: RII-CT-2006-062193, COMPARE: CIT5-CT-2005-028857, SHARELIFE: CIT4-CT-2006-028812) and FP7 (SHARE-PREP: No. 211909, SHARE-LEAP: No. 227822, SHARE M4: No. 261982). Additional funding from the German Ministry of Education and Research, the Max Planck Society for the Advancement of Science, the US National Institute on Aging (U01_AG09740-13S2, P01_AG005842, P01_AG08291, P30_AG12815, R21_AG025169, Y1-AG-4553-01, IAG_BSR06-11, OGHA_04-064, HHSN271201300071C) and from various national funding sources is gratefully acknowledged (see www.share-project.org).

Acknowledgements. I would like to thank the reviewers for their very useful comments.

Ethical standards. Ethical approval was not required.

\section{Notes}

1 The individuals compare two states (employment and retirement) and try to maximise their utility, considering the individual income/savings level, the benefits provided by the pension system and free time. There is a clear reference to the lifecycle hypothesis of savings (Modigliani, 1986), which maintains that the resources an individual/household allocate to consumption at any age depend on the life resources available.

2 In a review of recent longitudinal studies on retirement (Scharn et al., 2018), eight domains (demographic factors, health factors, social factors, social participation, work characteristics, financial factors, retirement preferences and macro effects) have been identified. Among the work characteristics are mainly aspects related to job demands (e.g. physically demanding job) and related to the work context, excluding De Preter et al. (2013) and Schils (2008), which consider whether the work is full-time or part-time and duration in employment before 50 years, respectively.

3 They replied 'yes' to the question: Have you ever done any paid work?

4 In Figure 1, contrary to what one would expect, the 'all' line is above that of voluntary and involuntary retirement. It can be due to the fact that in the case of the reasons for retirement there is a high number of missing cases (11,372 out of 29,591 observations).

5 The distinction between early, on time or later retirement has not been considered in the data analysis in this paper, as there is a measure of ambiguity, without an age that can be taken as a benchmark (Kholi et al., 1991). Taking account of the reforms under way in the Italian pension system, the benchmark age to define retirement as early would not always be the same but would change over time.

\section{References}

Antonova L, Aranda L, Pasini G and Trevisan E (2014) Migration, family history and pension: the second release of the SHARE Job Episodes Panel. Survey of Health, Ageing and Retirement in Europe, Working Paper Series 18-2014. Available at www.share-project.org/uploads/tx_sharepublications/WP_Series_18_ 2014_Antonova_Aranda_Pasini_Trevisan_02.pdf.

Auer P and Fortuny M (2000) Ageing of the labour force in OECD countries: economic and social consequences. International Labour Organization, Employment Paper 2000/2.

Avendano M and Mackenbach JP (2010) Life-course health and labour market exit in thirteen European countries: results from SHARELIFE. Mannheim Research Institute for the Economics of Aging (MEA), Discussion Paper 227-10.

Axelrad H (2018) Early retirement and late retirement: comparative analysis of 20 European countries. International Journal of Sociology 48, 231-250.

Barbieri P and Scherer S (2011) Retirement in Italy: rising social inequalities across generations. In Blossfeld HP, Buchholz S and Friedrich O (eds), Aging Populations, Globalization and the Labor Market. Comparing Late Working Life and Retirement in Modern Societies. Northampton, MA: Edgar Elgar, pp. 91-120.

Barbosa LM, Monteiro B and Giardini Murta S (2016) Retirement adjustment predictors - a systematic review. Work, Aging and Retirement 2, 262-280. 
Beckstette W, Lucchini M and Schizzerotto A (2006) Men's late careers and career exits in Italy. In Blossfeld HP, Buchholz S and Hofäcker D (eds), Globalization, Uncertainty and Late Careers in Society. Abingdon, UK: Routledge, pp. 101-118.

Blekesaune M and Solem PE (2005) Working conditions and early retirement. A prospective study of retirement behavior. Research on Aging 27, 3-30.

Blöndal S and Scarpetta S (1999) The retirement decision in OECD countries. Organisation for Economic Co-operation and Development, Economic Department Working Paper 202. Available at https://www. oecd-ilibrary.org/economics/the-retirement-decision-in-oecd-countries_565174210530.

Blossfeld HP, Buchholz S and Friedrich O (eds) (2011) Aging Populations, Globalization and the Labor Market. Comparing Late Working Life and Retirement in Modern Societies. Northampton, MA: Edgar Elgar.

Blossfeld HP, Buchholz S and Hofäcker D (eds) (2006) Globalization, Uncertainty and Late Careers in Society. Abingdon, UK: Routledge.

Börsch-Supan A, Brandt M, Hunkler C, Kneip T, Korbmacher J, Malter F, Schaan B, Stuck S and Zuber S (2013) Data resource profile: the Survey of Health, Ageing and Retirement in Europe (SHARE). International Journal of Epidemiology 42, 992-1001.

Börsch-Supan A, Brugiavini A and Croda E (2009) The role of institutions and health in European patterns of work and retirement. Journal of European Social Policy 19, 341-358.

Brugiavini A, Cavapozzi D, Pasini G and Trevisan E (2013) Working life histories from SHARELIFE: a retrospective panel. Survey of Health, Ageing and Retirement in Europe, Working Paper Series 11-201. Available at www.share-project.org/fileadmin/pdf_documentation/Working_Paper_Series/WP_Series_ 11_2013_Brugiavini_Cavapozzi_Pasini_Trevisan.pdf.

Cahill KE, Giandrea MD and Quinn JF (2006) Retirement patterns from career employment. The Gerontologist 46, 514-523.

Chan S and Stevens A (2004) How does job loss affect the timing of retirement? Contributions in Economic Analysis \& Policy 3, Article 5.

Contini B and Foriero E (2002) Scelte lavorative e di pensionamento degli anziani in Italia. Rome: Ministero del Lavoro e delle Politiche Sociali.

De Luigi N, Rizza R and Santangelo F (2016) Il traguardo è lontano e l'arrivo in salita: donne e pensioni in Italia. Stato e mercato 108, 451-481.

De Preter H, Van Looy D, Mortelmans D and Denaeghel K (2013) Retirement timing in Europe: the influence of individual work and life factors. Social Science Journal 50, 145-151.

Dingemans E, Henkens K and van Solinge H (2017) Working retirees in Europe: individual and societal determinants. Work, Employment and Society 31, 972-991.

Disney R, Grundy E and Led JP (1997) The Dynamics of Retirement (Research Report No. 72). London: Department of Social Security.

Dorn D and Sousa-Poza A (2010) 'Voluntary' and 'involuntary' early retirement: an international analysis. Applied Economics 42, 427-438.

Elder GH and Giele JZ (eds) (2009) The Craft of Life Course Research. New York, NY: The Guilford Press.

Esping-Andersen G (1990) Three Worlds of Welfare Capitalism. Cambridge: Polity Press.

Esping-Andersen G, Gallie D, Hemerijck A and Myles J (2002) Why We Need a New Welfare State. Oxford: Oxford University Press.

Feldman DC (1994) The decision to retire early: a review and conceptualization. The Academy of Management Review 19, 285-311.

Fisher GG, Chaffee DS and Sonnega A (2016) Retirement timing: a review and recommendations for future research. Work, Aging and Retirement 2, 230-261.

Ginn J and Arber S (1996) Patterns of employment, gender and pensions: the effect of work history on older women's non-state pensions. Work, Employment and Society 10, 469-490.

Hofäcker D, Schröder H, Li Y and Flynn M (2016) Trends and determinants of work-retirement transitions under changing institutional conditions: Germany, England and Japan compared. Journal of Social Policy 45, 39-64.

Humphrey A, Costigan P, Pickering K, Stratford N and Barnes M (2003) Factors Affecting the Labour Market Participation of Older Workers (Research Report No. 200). Leeds: Department for Work and Pensions.

ISFOL (2006) Rapporto sulla formazione continua 2005. Rome: Isfol. 
Kholi M, Rein M, Guillemard AM and van Gunsteren H (eds) (1991) Time for Retirement. Comparative Studies of Early Exit from the Labour Force. Cambridge: Cambridge University Press.

Korbmacher JM (2016) Recall error in year of retirement (v2). Survey of Health, Ageing and Retirement in Europe, Working Paper Series 21-2014.

Leinonen T, Chandola T, Laaksonen M and Martikainen P (2020) Socio-economic differences in retirement timing and participation in post-retirement employment in a context of a flexible pension age. Ageing \& Society 40, 348-368.

Loretto W and Vickerstaff S (2015) Gender, age and flexible working in later life. Work, Employment and Society 29, 233-249.

Marano A and Sestito P (2004) Older workers and pensioners: the challenge of ageing on the Italian public pension system and labour market. CeRP, Working Paper 32/04.

Mayer KU (2009) New directions in life course research. Annual Review of Sociology 35, 413-433.

Mills M (2011) Introducing Survival and Event History Analysis. London: Sage.

Modigliani F (1986) Life cycle, individual thrift, and the wealth of the nations. American Economic Review 76, 297-313.

Oakman J and Wells Y (2013) Retirement intentions: what is the role of push factors in predicting retirement intentions? Ageing \& Society 33, 998-1008.

Organisation for Economic Co-operation and Development (OECD) (2004) Ageing and Employment Policies. Italy. Paris: OECD Publishing.

Organisation for Economic Co-operation and Development (OECD) (2017) Pensions at a Glance 2017: OECD and G20 Indicators. Paris: OECD Publishing.

Organisation for Economic Co-operation and Development (OECD) (2019) Adult Learning in Italy. What Role for Training Funds? Paris: OECD Publishing.

Orso CE, Brugiavini A, Cavapozzi D and Pasini D (2017a) SHARE Job Episodes Panel. Release Version 6.0.0 (Data-set) SHARE-EriC. doi:10.6103/SHARE.jep.600.

Orso CE, Brugiavini A, Cavapozzi D and Pasini D (2017b) Brief Description of SHARE Job Episodes Panel Data Release 6.0.0. Available at http://www.share-project.org/fileadmin/pdf_documentation/SHARE_Job_ Episodes_Panel_Release_6-0-0.pdf.

Paci M (2005) Nuovi lavori, nuovo welfare. Sicurezza e libertà nella società attiva. Bologna, Italy: il Mulino.

Phillipson C (1998) Reconstructing Old Age. London: Sage.

Pierson P (ed.) (2001) The New Politics of the Welfare State. Oxford: Oxford University Press.

Ponomarenko V (2016) Cumulative disadvantages of non-employment and non-standard work for career patterns and subjective well-being in retirement. Advances in Life Course Research 30, 133-148.

Post C, Schneer JA, Reitman F and ogilvie dt (2012) Pathways to retirement: a career stage analysis of retirement age expectations. Human Relations 66, 87-112.

Reyneri E (2005) Sociologia del mercato del lavoro. Il mercato del lavoro tra famiglia e welfare. Bologna, Italy: il Mulino.

Riekhoff A-J (2016) De-standardisation and differentiation of retirement trajectories in the context of extended working lives in the Netherlands. Economic and Industrial Democracy 1-23. doi: 10.1177/ 0143831 X16669593.

Riekhoff A-J (2018) Institutional and socio-economic drivers of work-to-retirement trajectories in the Netherlands. Ageing \& Society 38, 568-593.

Sargent LD, Lee MD, Martin B and Zikic J (2012) Reinventing retirement: new pathways, new arrangements, new meanings. Human Relations 66, 3-21.

Scharn M, Sewdas R, Boot CRL, Huisman M, Lindeboom M and van der Beek AJ (2018) Domains and determinants of retirement timing: a systematic review of longitudinal studies. BMC Public Health 18, 1083.

Schils T (2008) Early retirement in Germany, the Netherlands, and the United Kingdom: a longitudinal analysis of individual factors and institutional regimes. European Sociological Review 24, 315-329.

Schizzerotto A (ed.) (2002) Vite ineguali. Disuguaglianze e corsi di vita nell'Italia contemporanea. Bologna, Italy: il Mulino.

Schröder M (ed.) (2011) Retrospective Data Collection in the Survey of Health, Ageing and Retirement in Europe. SHARELIFE Methodology. Mannheim, Germany: Mannheim Research Institute for the Economics of Aging (MEA). Available at www.share-project.org/uploads/tx_sharepublications/FRBMethodology_feb2011_color-1.pdf. 
Singer JD and Willett JB (2003) Applied Longitudinal Data Analysis. Modeling Change and Event Occurrence. New York, NY: Oxford University Press.

Steiber N and Kohli M (2017) You can't always get what you want: actual and preferred ages of retirement in Europe. Ageing \& Society 37, 352-385.

Turek K and Henkens K (2019) Accessibility of training in older age; a longitudinal European perspective. Netspar, Discussion Paper DP 04/2019-020.

van Solinge $\mathbf{H}$ and Henkens $\mathbf{K}$ (2007) Involuntary retirement: the role of restrictive circumstances, timing, and social embeddedness. Journals of Gerontology: Psychological Sciences and Social Sciences 62B, 295-303.

van Solinge $\mathbf{H}$ and Henkens $\mathbf{K}$ (2014) Work-related factors as predictors in the retirement decisionmaking process of older workers in the Netherlands. Ageing \& Society 34, 1551-1574.

Wang M and Schultz KS (2010) Employee retirement: a review and recommendations for future investigation. Journal of Management 36, 172-206.

Wang M and Shi J (2014) Psychological research on retirement. Annual Review of Psychology 65, 209-233.

Cite this article: Trentini M (2021). Retirement timing in Italy: rising age and the advantages of a stable working career. Ageing \& Society 41, 1878-1896. https://doi.org/10.1017/S0144686X20000148 